\title{
Genetic Analysis of Some Quality Traits in Maize
}

\section{Elif ÖZDEMIR ${ }^{* 1}$, Bayram SADE ${ }^{2}$ (D)}

\author{
${ }^{1}$ Selçuk Üniversitesi, Ziraat Fakültesi, Tarla Bitkileri Bölümü, Kampüs/KONYA \\ ${ }^{2}$ KTO Karatay Üniversitesi, Iktisadi ve Idari Bilimler Fakültesi, Enerji Yönetimi Bölümü, Karatay/KONYA
}

\begin{abstract}
Field experiments were conducted during the 2015 - 2016 growing seasons in Konya, Turkey. Seven inbred lines, 3 testers and $21 F_{1}$ progenies that were produced by line $x$ tester mating design in 2015 were used as materials. Seeds of each genotype were sown by hand to $5 \mathrm{~m}$ long rows according to "Randomized Complete Block Design" with three replications with spacing of $70 \times 20 \mathrm{~cm}$ in second week of May in 2016. Each replicate plot was consisted of two $5 \mathrm{~m}$ long rows. Corn cobs of parentages and crosses were harvested manually in October when the moisture content of the grains was approximately 20\%. Laboratory analyses were performed during the $2017-2018$ with seeds of 7 inbred lines, 3 testers and 21 hybrid maize combinations. Crude oil content (COC), crude protein content (CPC), hectolitre weight (HW), starch content (SC) and thousand grain weight (TGW) traits of each genotype were determined. The variance compounds of the population, general combining abilities (GCAs) of the parentages and specific combining abilities (SCAs) of the progenies were calculated. Line 3.2 (CPC; 0.448*, HW; 8.794*, TGW; 24.805**), line 3.4 (CPC; 0.054*, COC; 1.019**, HW; 23.905**), line 14.21 (CPC; $0.176^{* *}$, COC; 1.297**, HW; 18.349**), line 3.6 (COC; 1.441**, SC; $2.145^{* *}$ ), line 14.2 (SC; $1.675^{* *}$, HW; $21.460^{* *}$ ), line 14.26 (SC; $2.566^{* *}$, TGW; $35.550^{* *}$ ) and line 14.20 (CPC; $0.767^{* *}$ ) had significant and positive GCAs at several properties. Our results suggested that this population is suitable for developing progenies with appropriate quality traits.
\end{abstract}

Keywords: breeding, GCA, line $\times$ tester, SCA, quality in maize

\section{Mısırda Bazı Kalite Özelliklerinin Genetik Analizi}

Öz: Tarla denemeleri 2015 - 2016 yetiştirme sezonlarında Konya, Türkiye koşullarında yürütülmüştür. Denemede materyal olarak 7 ana, 3 baba hat ve 2015 yılında line $\times$ tester yöntemine göre üretilmiş $21 F_{1}$ kombinasyonuna ait tohumluklar kullanılmıştır. Her bir genotipe ait tohumluklar 2016 yılının Mayıs ayının ikinci haftası içerisinde el ile 5 m uzunluğundaki sıralara "Tesadüf Blokları Deneme Deseni" ne göre üç tekerrürlü olarak $70 \times 20$ ekim düzeninde ekilmişlerdir. Her bir parsel 5 m uzunluğunda iki sıradan oluşacak şekilde tasarlanmıştır. Ebeveynlerin ve melezlerin koçanları Ekim ayı içerisinde tane nem oranları yaklaşık \%20 olduğunda hasat edilmişlerdir. Laboratuvar analizleri 2017 - 2018 yıllarında yapılmış, analizlerde 7 ana hat, 3 test edici ve 21 melez mısır kombinasyonuna ait tohumluklar kullanılmıştır. Her bir genotipte ham yağ oranı (HYO), ham protein oranı (HPO), hektolitre ağırlığı (HA), nişasta içeriği (Ni) ve bin tane ağırlığı (BTA) özellikleri belirlenmiştir. Popülasyonun varyans bileşenleri, ebeveynlerin genel kombinasyon yeteneği (GKY), melezlerin ise özel kombinasyon yeteneği (ÖKY) değerleri hesaplanmıştır. Hat 3.2 (HPO; 0.448*, HA; 8.794*, BTA; 24.805**), 3.4 (HPO; 0.054*, HYO; 1.019**, HA; 23.905**), 14.21 (HPO; 0.176**, HYO; 1.297**, HA; 18.349**), 3.6 (HYO; 1.441**, Ni; $\left.2.145^{* *}\right), 14.2$ (Ni; $\left.1.675^{* *}, H A ; 21.460^{* *}\right), 14.26$ (Ni; 2.566**, BTA; 35.550**) ve 14.20 (HPO; $\left.0.767^{* *}\right)^{\prime}$ nin birçok özellikte pozitif ve önemli GKY değerlerine sahip oldukları izlenmiştir. Denemeden elde edilmiş bulgular denemeye konu popülasyonun arzu edilen kalite kriterlerine sahip melezlerin geliştirilmesine uygun olduğunu göstermiştir.

Anahtar Kelimeler: ıslah, GKY, line x tester, ÖKY, mısırda kalite

\section{INTRODUCTION}

Cereals are one of the basic elements of trade and provide an important component of human nutrition. Cereal grains are also important sources of energy for domesticated animals (Chanpek et al., 2014). The annual global production of corn surpasses that of all other grains (1 billion tonnes), followed by wheat (751 million tonnes) and rice (482 million tonnes) (Anonymous 2017). Dent corn Zea mays indentata Sturt.- is a cereal from Gramineae and belong to Maydeae (Emeklier, 2012). Maize is an industrial crop that provides a source of starch, syrup, glucose, gluten and oil. The economic and nutritional value of maize grains is mainly due to its high starch (73\%), protein (9\%) and oil (4\%) contents (Musila et al., 2010). Nearly 49\% of grown maize is currently being utilised as raw material in the animal feed industry. Maize has a wide variety of uses (Mahesh et al., 2013) and so developing higher quality maize is gaining intense scientific interest (Ding et al., 2011). Plant breeding has been very successful in producing higher - yielding maize genotypes. By exploiting genetic variation in corn, the composition of the kernel has been altered to improve both the quantity and quality of starch, protein and oil (Singh et al., 2014). Sprague and Tatum (1942) defined GCA as the 'average of a line in hybrid

Sorumlu Yazar: elifyetim@selcuk.edu.tr Bu araştırma Selçuk Üniversitesi, Bilimsel Araştırma Projeleri Birimi tarafından desteklenmiştir. Proje No: 18401014

Geliş Tarihi: 14 Haziran 2019

Kabul Tarihi: 13 Aralık 2019 
combination' and defined SCA as the 'deviation of certain crosses from expectation on the basis of the average performance of the line. Nagma et al., (2014) reported that the combining ability of an inbred line is the factor that ultimately determines its usefulness in the production of hybrid and synthetic plants; thus, GCA values of parentages used in breeding programmes must be known by breeders (Machkiowa et al., 2011). Analysis of the combining ability is one of the most powerful approaches for identifying the best combiners to be used in crosses, either to accumulate functional genes. Knowing the combining ability also helps one understand the genetic architecture of various attributes, which enables breeders to design effective breeding plans to develop valuable lines (Singh et al., 2017). Effective parental selection is very important for producing high - quality, single - cross hybrids. Breeders normally focus on producing inbred parents with high GCAs and hybrids with high SCAs (Patil et al., 2012). The present study aims to provide insights into methods for increasing desirable traits related to grain quality of maize (COC, CPC, $\mathrm{HW}, \mathrm{SC}, \mathrm{TGW}$ ) and provides materials to different usage areas of industry.

\section{MATERIALS AND METHODS}

\section{Plant Materials}

In our trials, we used seven inbred lines [Origin: Turkey; Generation: S7; Maturity Group: Late) 3.2, 3.4, 3.6, 14.2, 14.20, 14.21 and 14.26)], three testers [FRMo 17 (USA), FRB 73 (USA) and ADK 451 (Turkey)] and 21 hybridised $F_{1}$ progenies.

\section{Field Experiment}

The seven inbred lines and 3 testers were crossed to produce $21 \mathrm{~F}_{1}$ hybrid progenies following the line $\times$ tester mating design developed by Kempthorne (1957) in 2015 growing season. The various maize accessions were grown in a randomized complete block design with three replications in 2016. Seeds of each genotype were sown by hand in the second week of May with a spacing of $70 \times 20$ $\mathrm{cm}$. Each replicate plot of a particular accession consisted of two $5 \mathrm{~m}$ long rows. Cultural practices, as described by Kirtok (1998), were followed.

Corn cobs from parents and crosses were harvested manually in October when the moisture content of the grains was approximately $20 \%$.

\section{Laboratory Analysis}

All laboratory analyses were performed during 2017 - 2018. Cobs of parents and crosses were air - dried after harvesting under standard room conditions. Whole grains were used to determine Hectolitre Weight (HW) and Thousand Grain Weight (TGW). Milled grain samples were used to determine Crude Oil Content (COC), Crude Protein Content (CPC) and Starch Content (SC). Percent Crude Oil
Content (COC) was determined following Khan et al. (2016) via the soxhlet method. Percent Crude Protein Content (CPC) was determined following the procedures used by Mosse (1990) using a Leco Truspec CHNS elemental analyser. Hectolitre weight values (kg $\left.\mathrm{h} \mathrm{I}^{-1}\right)$ were determined with a PM - 400 hectolitre weight scale. Percent Starch Content (SC) was determined according to Alan et al. (2011). Four replicates of 100 randomly collected seeds were counted. Each seed group replicate was weighed. The obtained values were converted to Thosand Grain Weight (TGW). We used SPSS version 20.0 to statistically analyse all data. We performed analysis of variance for a randomised complete block design. We calculated the heritability components $\left[v^{2}\right.$ (Variance) GCA (General Combining Ability), $v^{2}$ (Variance) SCA (Specific Combining Ability), RV (Relative Variance), $v^{2}$ (Variance) A (Additive), $v^{2}$ (Variance) D (Dominance), $\left.\left.\sqrt{ } D / A\right)\right]$, GCAs (General Combining Abilities) of the parentages and SCAs (Specific Combining Abilities) of the progenies as described by Singh and Chaudhary (1979) and Hussain and Sulaiman (2011). The Relative Variance (RV) was calculated as described by Fasahat et al. (2016). The t-test being used to test the significance of the GCAs (General Combining Abilities) and SCAs (Specific Combining Abilities)

\section{RESULTS AND DISCUSSION}

\section{Variance Components}

Results of the analysis of variance for all attributes are summarised in Table 1. For each feature, its variation among genotypes was statistically significant $(P<0.01)$, suggesting a remarkable amount variation that promoted the investigation of the genotypes.

When variations among variance components of the population in the trial were investigated, we observed that $U^{2} S C A>U^{2} G C A$ for the traits COC, CPC and TGW and $U^{2} D>$ $U^{2} A$ for the traits COC and TGW. $v^{2} G C A>v^{2} S C A$ for $H W$ and $\mathrm{SC}$ and that in all $v^{2} A s$ was $>v^{2} \mathrm{Ds}$ (Table 2). The RVs ranged from 0.260 to 0.832 . The $\mathrm{RV}$ of the $\mathrm{SC}$ trait was higher than it was for any of the other traits, followed by $\mathrm{HW}, \mathrm{CPC}$ and COC. The minimum RV value was obtained for the TGW attribute. The observation that $U^{2} D>v^{2} A$ of the TGW and COC traits indicated high dominance effects on these properties; high $\sqrt{ } \mathrm{D} / \mathrm{A}$ values support these results as well (Table 2). Dominant gene effects were not observed for most of the other attributes (except for TGW and COC). For attributes (traits) under the influence of GCA, additive gene effects operate, whereas for traits under the influence of SCA, non - additive, dominant and / or epistasis gene affecting $\mathrm{HW}$ and SC properties in the population we studied were under the influence of additive genes, effects operate (Tan, 2010; Rodrigo et al., 2012; Tongbram 
Table 1. Analysis of variance for features at the parents and their F1 progenies of maize

\begin{tabular}{lllllll}
\hline Sources & d.f. & COC (\%) & CPC (\%) & HW $\left.\mathbf{~ ( k g . h ~}^{-1}\right)$ & SC (\%) & TGW (g) \\
\hline Replications & 2 & 0.885 & $0.106^{*}$ & $17332.052^{* *}$ & 2.455 & $23238.460^{* *}$ \\
Genotypes & 30 & $459.456^{* *}$ & $58.874^{* *}$ & $129368.835^{* *}$ & $804.735^{* *}$ & $378399.756^{* *}$ \\
Error & 60 & 18.915 & 1.930 & 62517.580 & 57.671 & 323730.780 \\
Total & 92 & 479.256 & 60.910 & 209218.467 & 864.861 & 725368.995 \\
CV (\%) & & 11.68 & 2.10 & 4.41 & 1.55 & 23.54 \\
\hline
\end{tabular}

** P < 0.01; COC: Crude Oil Content ; CPC: Crude Protein Content ; HW: Hectolitre Weight; SC: Starch Content; TGW: Thousand Grain Weight

${ }^{1}$ Coefficient of variation.

and Baskheti, 2014). Therefore, we speculate that genes whereas COC, CPC and TGW were under the influence of non - additive genes. Similarly, Singh et al. (2017) and Mahesh et al. (2013) revealed that $v^{2} G C A>v^{2}$ SCA for SC and $v^{2} S C A>v^{2} G C A$ for $C O C$ and CPC traits. Likewise, Ding et al. (2011) and lqbal et al. (2007) reported that $v^{2}$ SCA > $\mathrm{U}^{2} \mathrm{GCA}$ for HW and TGW traits. The variance components of every trait depend on the genetic makeup of the population. Different gene effects / actions can affect inheritance of characters in a population as well. Additive variance associated with the average effects of individual genes measures the breeding value of the population and can always be changed via selection (Sofi et al. 2007). Populations are more suitable for selective breeding if they possess properties with higher $\mathrm{U}^{2} \mathrm{~A}$ and for heterosis (Hs) breeding if they possess higher $v^{2} D$. Based on previous studies, this population is suitable for selective breeding for $\mathrm{HW}, \mathrm{SC}$ and CPC and suitable for Hs breeding for obtaining COC and TGW. Li et al. (2017) reported that if the degree of dominance $(\sqrt{ } D / A)$ for any character in the population is between 0.20 (inclusive) and 0.80 , then partial dominance occurs, whereas dominance occurs if $0.80 \leq \sqrt{D} / A<1.20$ and super dominance occurs if $\sqrt{ } D / A \geq 1.20$. Therefore, super dominance for $\mathrm{COC}$ and TGW got attention with higher $v^{2} D$. Dominance is very effective in populations that include genotypes with different genetic bases (Nagma et al. 2014). Dominance variance is associated with intra allelic gene interactions at segregating loci and so measures breeding behaviour of alleles of heterozygotes, a fact that Table 2. Variance components of the population for each traits can be practically applied in heterosis breeding (Sofi et al. 2007). Sometimes, additive and non-additive gene effects operate together in establishing some traits. Relative variance is a criterion used to determine the rate of additive and non-additive gene effects on specific traits. Relative variance values closer to 1.0 indicate more additive gene effects than non-additive gene effects (Fasahat et al. 2016). In the population we studied, additive gene effects were more effective in producing the SC trait than the $\mathrm{COC}$, $\mathrm{CPC}$ and HW traits, whereas non - additive genes effects were more effective in producing the TGW trait (Table 2).

\section{General Combining Ability}

Estimates for GCAs and SCAs for five attributes in 21 crosses are presented in Table 3. Most inbred lines exhibited significant and positive GCAs in various traits: lines 3.2, 14.21 and 3.4 in CPC, lines 3.6, 14.20, 14.21 and 3.4 in COC, lines 3.4, 14.2, 14.21 and 3.2 in HW, and lines 14.26, 3.6 and 14.2 in SC. Only lines 14.26 and 3.2 had significant and positive GCAs in TGW. Lines 3.4 and 14.21 had significant and positive GCAs at COC, CPC and HW traits; these parentages had significant and negative GCAs at SC trait as well. A remarkable similarity was observed of GCAs of lines 3.4 and 14.21 at different features. Tan (2010) reported that combining ability is the ability to transfer desired parental traits to $F_{1}$ progenies. Therefore, breeders must know the GCAs of parents used in breeding programmes (Machkiowa et al. 2011). Nagma et al. (2014) reported that the combining ability of an inbred line is the ultimate factor determining its use in the production of

\begin{tabular}{|c|c|c|c|c|c|c|}
\hline \multirow[b]{2}{*}{ Traits } & \multirow[b]{2}{*}{$v^{2} \mathrm{GCA}$} & \multirow[b]{2}{*}{$v^{2} S C A$} & \multicolumn{3}{|l|}{ Relative Variance } & \multirow[b]{2}{*}{$\sqrt{D} / A$} \\
\hline & & & $\begin{array}{l}{\left[2 v^{2} G C A \quad / \quad\left(2 v^{2} G C A+\right.\right.} \\
\left.\left.v^{2} S C A\right)\right]\end{array}$ & $U^{2} A$ & $U^{2} D$ & \\
\hline COC (\%) & 1.083 & 5.413 & 0.286 & 2.165 & 5.413 & 1.581 \\
\hline CPC (\%) & 0.198 & 0.313 & 0.558 & 0.395 & 0.313 & 0.889 \\
\hline HW (kg/l) & 620.014 & 331.582 & 0.789 & 1240.027 & 331.582 & 0.517 \\
\hline SC (\%) & 3.319 & 1.340 & 0.832 & 6.639 & 1.340 & 0.449 \\
\hline TGW (g) & 198.724 & 1131.391 & 0.260 & 397.447 & 1131.391 & 1.687 \\
\hline
\end{tabular}

COC: Crude Oil Content ; CPC: Crude Protein Content ; HW: Hectolitre Weight; SC: Starch Content; TGW: Thousand Grain Weight 
hybrid and synthetic varieties. The inbred parents 3.4, 14.21 and 3.6 exhibited significant and positive GCAs in COC; in addition, the lines 3.2, 14.2, 14.20 and 14.26 exhibited significant and negative GCAs, which indicated the potential of the parents for effectively transmitting genetic materials essential for a given attribute to their progenies (Topal et al., 2004) and so indicated the potential of them to produce high or low oil content genotypes. The SCAs of the hybrids of lines 3.4, 14.21 and 3.6 were significant and positive as well (Table 3). Singh et al. (2014) reported that high quality maize oil is particularly suitable for human consumption. The oil of maize is considered to be better than most of other edible oils due to its fatty acid composition and its stability during storage and cooking. Maize kernels are composed of $3-4 \%$ oil. However, more than $7 \%$ oil has been reported from high oil content genotypes (Singh et al., 2014). Oil from maize has a greater feed efficiency than normal maize when fed to animals. Maize oil contains 2.25 times more calories than starch Table 3. Estimation of GCA in parents and SCA in the F1 progenies for all traits

\begin{tabular}{|c|c|c|c|c|c|}
\hline GCA (parents) & $\operatorname{coc}(\%)$ & CPC (\%) & HW (kg.hl $\left.{ }^{-1}\right)$ & SC (\%) & TGW (g) \\
\hline 3.2 & $-1.125^{* *}$ & $0.448 * *$ & $2,002^{*}$ & $-4.135 * *$ & $24.805^{*}$ \\
\hline 3.4 & $1.019 * *$ & $0.054 *$ & $5,442 * *$ & $-0.281^{*}$ & -7.168 \\
\hline 3.6 & $1.441^{* *}$ & $-0.200 * *$ & $-3,664 * *$ & $2.145^{* *}$ & 1.723 \\
\hline 14.2 & $-1.592 * *$ & $-0.749 * *$ & $4,885 * *$ & $1.675 * *$ & $-49.875 * *$ \\
\hline 14.20 & $-0.714 * *$ & $0.767 * *$ & 0,510 & $-0.516 * *$ & -1.167 \\
\hline 14.21 & $1.297 * *$ & $0.176 * *$ & $4,177^{* *}$ & $-1.455^{* *}$ & -3.868 \\
\hline 14.26 & $-0.325 * *$ & $-0.495 * *$ & $-13,352^{* *}$ & $2.566 * *$ & $35.550 * *$ \\
\hline FRMo 17 & $-0.321 * *$ & $0.147 * *$ & $3,913^{* *}$ & $-0.654 * *$ & -1.297 \\
\hline FRB 73 & $0.937 * *$ & $-0.400 * *$ & 1,294 & $-0.611 * *$ & -22.002 \\
\hline ADK 451 & $-0.616 * *$ & $0.253^{* *}$ & $-5,207 * *$ & $1.264^{* *}$ & $23.300 *$ \\
\hline \multicolumn{6}{|c|}{ SCA (combinations) } \\
\hline $3.2 \times$ FRMo 17 & $0.154^{*}$ & $-0.027 * *$ & 0,440 & $-1.000 * *$ & $-13.670 * *$ \\
\hline 3.2 × FRB 73 & $-1.003 * *$ & $0.806 * *$ & $-2,256 * *$ & -0.164 & $42.209 * *$ \\
\hline $3.2 \times$ ADK 451 & $0.849 * *$ & $-0.779 *$ & $1,816 * *$ & $1.163^{* *}$ & $-28.539 *$ \\
\hline 3.4 × FRMo 17 & $3.910 * *$ & $0.051 * *$ & $-2,005^{* *}$ & $0.860 * *$ & $21.363^{* *}$ \\
\hline 3.4 × FRB 73 & $-2.214^{* *}$ & $-0.330 * *$ & $-0,900 *$ & $0.313^{*}$ & $-30.060 * *$ \\
\hline $3.4 \times$ ADK 451 & $-1.695 * *$ & $0.279 * *$ & $2,905^{* *}$ & $-1.174 * *$ & 8.698 \\
\hline 3.6 × FRMo 17 & $-2.013^{* *}$ & $-0.086 * *$ & $-1,271 * *$ & $-0.562 * *$ & $31.618 * *$ \\
\hline 3.6 × FRB 73 & $1.597 * *$ & $0.173 * *$ & $2,400 * *$ & $0.334^{*}$ & $-38.090 * *$ \\
\hline $3.6 \times$ ADK 451 & $0.416 * *$ & $-0.086 * *$ & $-1,129 * *$ & 0.228 & 6.473 \\
\hline $14.2 \times$ FRMo 17 & 0.121 & $-0.881 * *$ & $-0,760$ & $0.305^{*}$ & 11.364 \\
\hline $14.2 \times$ FRB 73 & $-1.037 * *$ & $0.122 * *$ & 0,144 & $-0.461 * *$ & $31.759 * *$ \\
\hline 14.2 × ADK 451 & $0.916^{* *}$ & $0.759 * *$ & 0,616 & $0.156^{* *}$ & $-43.123 * *$ \\
\hline $14.20 \times$ FRMo 17 & $-0.357 * *$ & $0.462 * *$ & $3,829 * *$ & $-2.163 * *$ & $-25.362 * *$ \\
\hline $14.20 \times$ FRB 73 & $0.519 * *$ & $-0.690 * *$ & 0,400 & $1.369 * *$ & $24.875^{*}$ \\
\hline $14.20 \times$ ADK 451 & $-0.162^{*}$ & $0.228 * *$ & $-4,229 * *$ & $0.794 * *$ & 0.488 \\
\hline $14.21 \times$ FRMo 17 & $-2.268 * *$ & $0.089 * *$ & 0,784 & $2.171 * *$ & 5.874 \\
\hline 14.21 × FRB 73 & $4.141^{* *}$ & -0.009 & $-1,344 * *$ & $-0.762 * *$ & $-38.982 * *$ \\
\hline $14.21 \times$ ADK 451 & $-1.873^{*}$ & $-0.080 * *$ & 0,560 & $-1.409 * *$ & $33.108 * *$ \\
\hline $14.26 \times$ FRMo 17 & $-1.168 * *$ & $-0.278 * *$ & $-8,716 * *$ & $4.410 * *$ & 8.232 \\
\hline 14.26 × FRB 73 & $-3.625 * *$ & $-0.743 * *$ & $-6,144 * *$ & $3.391 * *$ & $47.707 * *$ \\
\hline $14.26 \times$ ADK 451 & -0.073 & $-0.991 * *$ & $-8,240 * *$ & $4.261 * *$ & $62.313^{* *}$ \\
\hline
\end{tabular}

${ }^{*} \mathrm{P}<0.05 ;{ }^{* *} \mathrm{P}<0.01$; COC: Crude Oil Content ; CPC: Crude Protein Content ; HW: Hectolitre Weight; SC: Starch Content; TGW: Thousand Grain Weight

(based on dry weight) and possesses a beneficial composition of fatty acids (oleic and linoleic acids). Starch and oil concentrations have been shown to be negatively correlated in corn. For this population; If the aim of a breeding programme is to increase the oil content, then lines with positive GCAs in COC must be used. However, if the aim of a breeding programme is to increase SC, then parents with low GCAs in COC should be used. Therefore, appropriate GCA values for lines depend on the aims of the specific breeding programme. We observed high inheritance of the CPC trait in the lines 3.4, 3.2 and 14.21, which proves that these parents have the potential to produce hybrids containing high amounts of proteins. The hybrids of these parental lines also exhibited high SCAs (Table 2). Schaefer (1946) reported that proteins are essential nutrients required for proper nutrition in animals. In addition to providing nutrition for animals, products of proteins can be used as secondary materials in industrial 
applications. For example, corn gluten meal is one of the products used in producing corn starch, which is comprised of approximately $60 \%$ protein. Due to the insolubility of corn protein in water, corn is usually used for animal feeds rather than for human consumption (Schafer, 1946). Sun et al., (2018) reported that oligo - peptides prepared from corn gluten meal protects mitochondria against oxidative damage caused by ROS. Because corn protein potentially provides many commercially useful products, more scientific research is needed on producing corn hybrids that can supply proteins for commercial markets. The inbred lines 3.2, 14.21, 14.2 and 3.4 exhibited significant and positive GCAs in trait $\mathrm{HW}$, which indicates that the combinations of these parents would be useful for providing progenies with high HW. Some progenies of these lines exhibited significant and positive SCAs as well. HW in maize is linked to kernel maturity, integrity and uniformity and so it is not only an important index of grain quality but also an important factor for determining the market corn grades for milling, exporting and other purposes. In addition to the chemical compounds inherent to maize kernels, physical factors (e.g. endosperm hardness, kernel size, water content) and kernel type have also been found to significantly correlate with HW (Ding et al., 2011). High HW indicates high grain size, endosperm hardness and protein content. A selection program focused on one of those traits may provide information to the breeder about the other factors that correlate with such traits. Better information on HW may also enable breeders to evaluate populations more efficiently and provide better information to breeders on traits other than those being specifically investigated. The lines 14.2, 3.6 and 14.26 exhibited significant and positive GCAs in SC; line 14.26 also exhibited significant and positive GCA in the TGW trait. All progenies of line 14.26 had significant and positive SCAs in SC as well. We observed a remarkable relationship between SC and TGW attributes in the inbred line 14.26. Some progenies of the lines 3.6 and 14.2 also exhibited significant and positive SCAs in SC. Based on these results, lines 3.6, 14.2 and 14.26 were good combiners (GCS) for SC and lines 3.2 and 14.26 were GCs for TGW. Corn kernels contain about $77 \%$ starch. Corn starch is a major ingredient used in cooking and in many industrialised food products (Mahesh et al., 2013). Maize starch has a wide range of usage areas industry, such as providing a source of synthetic polymers in food packaging (Wang et al., 2017), an alternative source for starch for celiac patients, etc. (Chnapek et al., 2014). Linear correlations have been observed among traits the $\mathrm{CPC}$ and $\mathrm{HW}, \mathrm{COC}$ and CPC, CPC and HW and SC and TGW in many studies (Dorsey - Redding et al., 1991; Saleem et al., 2008; Aliu et al., 2012). We found that lines 3.4, 14.21 and 14.26 also exhibited significant and positive GCAs for traits the $\mathrm{COC}$ - CPC - HW, COC - CPC - HW and SC - TGW. Correlations of GCAs of some of the traits can provide benefits to the breeders, interested in selection with more criteria in shorter times.

\section{Specific Combining Ability}

Some of the crosses and combinations of parentages (by GC or poor combiner [PC]) are summarised at Table 3 . While progenies $14.21(+\mathrm{GC}) \times \mathrm{FRB} 73(+\mathrm{GC})$ and $3.4(+\mathrm{GC}) \times$ FRMo $17(-\mathrm{GC})$ had significant, positive and high SCAs in COC; 3.2 $(-\mathrm{GC}) \times$ FRMo $17(-\mathrm{GC})$ and $3.6(+\mathrm{GC}) \times$ ADK 451 (-GC) had significant, positive and low SCAs. Tester FRMo 17 took part in two of the combinations as a GC with a negative orientation. Parentages that have opposite gene actions from each other, had progenies with significant and positive SCAs in COC (Table 3). The progenies $3.2(+G C) \times$ FRB 73 $(-G C)$ and $14.2(-G C) \times$ ADK $451(+G C)$ showed significant, positive and high SCAs in CPC, whereas $3.4 \times$ FRMo 17 and $14.21 \times$ FRMo 17 showed significant, positive and lower SCAs in CPC. Unlike COC; tester FRMo 17 was a GC with positive orientation among some progenies at CPC (Table 3). Following progenies were observed with remarkable SCAs in HW. Progenies 14.20 (PC) $\times$ FRMo $17(+\mathrm{GC})$ and 3.2 $(+G C) \times A D K 451(-G C)$ showed significant, positive and high SCAs, whereas $14.21(+\mathrm{GC}) \times$ ADK $451(-\mathrm{GC})$ and $3.4(+\mathrm{GC}) \times$ ADK 451 (-GC) showed significant, positive and lower SCAs. The progeny of $14.20(P C) \times$ FRMo $17(+G C)$ had the highest SCA, though a poor combiner parent. The progenies $14.21 \times$ ADK $451(-G C)$ and $3.2 \times$ ADK 451 (-GC) were also remarkable progenies with good and negative oriented parents. The observation of SCAs in the SC of progenies showed that $14.26(+\mathrm{GC}) \times$ FRMo $17(-\mathrm{GC})$ and $14.26(+\mathrm{GC})$ $\times$ ADK 451 (+GC) showed significant, positive and high SCAs, whereas the progenies $14.2(+\mathrm{GC}) \times$ ADK $451(+\mathrm{GC})$ and $14.2(+\mathrm{GC}) \times$ FRMo $17(-\mathrm{GC})$ had significant, positive and lower SCAs. All parentages of these four progenies were good combiners therewithal a good combiner FRMo 17, had a negative orientation (Table 3 ). We observed several progenies with remarkable SCAs. The ones that had significant, positive and the highest SCAs were progenies $14.26(+\mathrm{GC}) \times \mathrm{ADK} 451(+\mathrm{GC}), 14.26(+\mathrm{GC}) \times \mathrm{FRB} 73(-\mathrm{PC})$, $14.20(-P C) \times$ FRB $73(-P C)$ and $3.4(-P C) \times$ FRMo $17(-P C)$ and three of the previous progenies with the highest SCAs had PC in their gene pools. The SCAs of progenies $14.21 \times$ FRB 73 and $14.20 \times$ FRMo 17 were significant and positive. Fasahat et al., (2016) reported that progenies with high SCAs, where both parents were GCs may indicate the occurrence of additive $\times$ additive gene actions with respect to the trait in question. High value hybrids between good and poor general combiner parents may be attributed to favourable additive effects from the GC parent and to favourable epistasis effects from the poor general combiner parent. High performance from hybrids between low $\times$ low parents may be due to dominance $x$ dominance types of non - allelic gene interactions, resulting in over dominance. Many of our progenies had significant positive or negative SCAs. We observed that parents of some progenies exhibiting significant and positive SCAs showed dominance/epistasis gene actions in HW and TGW traits. Furthermore, the TGW trait was also under the influence of non - additive genes. The same was not observed for the HW attribute because one of the parentages of our progenies exhibited additive gene action many times. This may explain why $v^{2}$ GCA $>v^{2}$ SCA in the TGW trait, whereas remarkable epistasis effects of tester. The influence of high GCA can confer stability to a genotype, but high SCA levels 
for any trait (which occurs under dominance $x$ dominance gene effects) can be used more effectively in SCA breeding studies. Therefore, Tan (2005) reported that lines that have greater genetic distance are better combiners. According to the scientific literature and our results, parentages in our experimental population had a wide range of genetic variation.

\section{CONCLUSIONS}

According to the results; line 3.2 (CPC; 0.448*, HW; 8.794*, TGW; 24.805**), line 3.4 (CPC; 0.054*, COC; 1.019**, HW; $23.905^{* *}$ ), line 14.21 (CPC; 0.176**, COC; $1.297^{* *}$, HW; $\left.18.349^{* *}\right)$, line 3.6 (COC; $1.441^{* *}$, SC; $\left.2.145^{* *}\right)$, line 14.2 (SC; $1.675^{* *}$, HW; 21.460**), line 14.26 (SC; 2.566**, TGW; $35.550^{* *}$ ) and line 14.20 (CPC; $0.767^{* *}$ ) had significant and positive GCAs at several properties. In the study many of the progenies had significant and positive SCAs at many properties as well. Progeny $3.2 \times$ ADK 451 [COC (0.849**); HW $\left(1,816^{* *}\right) ;$ SC $\left.\left(1,163^{* *}\right)\right], 14.20 \times$ FRB 73 [COC $\left(0,519^{* *}\right)$; SC $\left(1,369^{* *}\right)$; TGW $\left.\left(24.875^{* *}\right)\right], 3.4 \times$ FRMo 17 [COC $\left(9,910^{* *}\right) ;$ CPC $\left(0.051^{* *}\right) ;$ SC $\left(0,860^{* *}\right) ;$ TGW $\left(21.363^{*}\right)$ ] and $3.6 \times$ FRB 73 [COC $\left(1.597^{* *}\right) ;$ CPC $\left(0.173^{* *}\right)$; HW $\left(2.400^{* *}\right)$; (SC $\left(0,334^{*}\right)$ ] had significant and positive SCAs many of the progenies as well. Our results suggested that this population is suitable for developing progenies with appropriate quality traits.

\section{REFERENCES}

Alan Ö, Sönmez K, Budak Z, Kutlu I, Ayter NÖ (2011) The effect of sowing dates on yield and agricultural characteristics of sweet corn (Zea mays saccharata Sturt.) in Eskisehir ecological conditions. Journal of Selcuk Agriculture and Food Sciences, 25: 34-41.

Aliu S, Rusinovci I, Fetahu S, Rozman L (2012) Genetic diversity and correlation for grain yield and quality traits in local maize (Zea mays L.). Notulae Scientia Biologicae, 4: 126-130.

Anonymous (2017) 2016 Yılı Hububat Raporu. Turkish Grain Board Publishes, Ankara.

Chnapek M, Tomka M, Gregánová Z, Gálová Z (2014) Protein complex of wheat, buckwheat and maize in relation to celiac disease. The Journal of Microbiology, Biotechnology and Food Sciences, 3: 88-92.

Ding J, Ma J, Zhang C, Dong H, Xi Z, Xia Z, Wu J (2011) QTL mapping for test weight by using $\mathrm{F} 2: 3$ population in maize. Journal of Genetics, 1: 75-80.

Dorsey-Redding C, Hurburg RC, Johnson LA, Fox SR (1991) Relationships among maize quality factors. Cereal Chemistry, 68: 602-605.

Emeklier Y (2012) Sıcak Iklim Tahılları. Ankara Üniversitesi Ziraat Fakültesi Yayınları, Ankara, p.119.

Fasahat P, Rajabi A, Rad JM, Derera J (2016) Principles and utilization of combining ability in plant breeding. Biom. Biostat. Int. J, 4: 1-24.

Hussain AH, Sulaiman RI (2011) Estimation of some parameters, heterosis and heritability for yield and morhological traits in inbred line of maize (Zea mays
L.) using line $x$ tester method. Journal of Tikrit University for Agricultural Sciences, 11: 359-383.

Iqbal AM, Nevhi SA, Wani SA, Rehana Q, Dar ZA (2007) Combining ability analysis for yield and yield related traits in maize (Zea mays L.). International Journal of Plant Breeding and Genetics, 1: 101-107.

Iqbal M, Khan K, Rahman H, Khalil IH, Sher H, Bakht J (2010) Heterosis for morphological traits in subtropical maize (Zea mays L.). Maydica, 55: 38-41

Kempthorn O (1957) An Introduction Genetic Statistics. The lowa State Uni. Press, lowa, p.564.

Khan S, Dadheech A, Dubey RB, Bharti B (2016) Combining ability and gene action studies for grain yield and quality parameters in yellow seeded maize (Zea mays L.) using linex tester crosses. International Journal of Bio-Resource and Stress Management, 7: 508-514.

Kirtok Y (1998) Mısır; Üretimi ve Kullanımı. Kocaoluk Yayıncılık Sanayi ve Ticaret Ltd. Şti., Adana, p.445.

Li H, Yang Q, Fan N, Zhang M, Zhai H, Ni Z, Zhang Y (2017) Quantitative trait locus analysis of heterosis for plant height and ear height in an elite maize hybrid zhengdan 958 by design III. BMC Genetics, 18: 2-10.

Machikowa T, Saetang C, Funpeng K (2011) General and specific combining ability for quantitative characters in sunflower. Journal of Agricultural Science, 3: 91-95.

Mahesh N, Wali MN, Gowda MVC, Motagi BN, Uppinal NF (2013) Genetic analysis of grain yield, starch, protein and oil content in single cross hybrid maize. Karnataka J. Agric. Sci., 26: 185-189.

Mosse J (1990) Nitrogen to protein conversion factor for ten cereals and six legumes or oilseeds, a reappraisal of its definition and determination, variation according to species and to seed protein content. J. Agric. Food Chem., 38: 17-24.

Musila RN, Diallo AO, Makumbi D, Njoroge K (2010) Combining ability of early-maturing quality protein maize inbred lines adapted to Eastern Africa. Field Crops Research, 119: 231-237.

Nagma K, Baskheti DC, Mamta S, Devi E (2014) Combining ability analysis for grain yield and agronomic characters in maize (Zea mays L.). Environment \& Ecology, 32: 461-464.

Patil AE, Charjan SU, Patil SR, Udasi RN, Puttawar MR, Palkar AB (2012) Studies on heterosis and combining ability analysis in maize (Zea mays L.). Journal of Soils and Crops, 22: 129-138.

Rodrigo O, Faria MV, Neumann M, Battistelli GM, Tegoni RG, Resende JTV (2012) Genetic divergence among maize hybrids and correlations with heterosis and combining ability. Acta Scientiarum Agronomy, 34: 37-44.

Saleem M, Ahsan M, Aslam M, Majeed A (2008) Comparative evaluation and correlation estimates for grain yield and quality attributes in maize. Pak. J. Bot., 40: 2361-2367.

Schaefer HC (1946) The role of proteins in animal nutrition. Oil and Soap, 1: 375-379. 
Singh RK, Chaudhary BD (1979) Biometrical Methods in Quantitative Genetic Analysis, Kalyani Publishers, New Delhi, p. 318.

Singh N, Vasudev S, Yadava DK, Chaudhary DP, Prabhu KV (2014) Oil Improvement In Maize: Potential and Prospects. In Dharam C, Sandeep K, Langyan S (eds) Maize: Nutrition Dynamics and Novel Uses. Springer, Indian, p. 77-82.

Singh M, Dubey RB, Ameta KD, Haritwal S, Bhagchand O (2017) Combining ability analysis for yield contributing and quality traits in yellow seeded late maturing maize (Zea mays L.) hybrids using line $\mathrm{x}$ tester. Journal of Pharmacognosy and Phytochemistry, 6: 112-118.

Sofi PA, Rather AG, Warsi MZK (2007) Implications of epistasis in maize breeding. International Journal of Plant Breeding and Genetics, 1: 1-11.

Sprague GF, Tatum LA (1942) General vs. specific combining ability in single crosses of corn. Agronomy Journal, 34: 923-932.

Sun N, Xu T, Liu Y, Ye C, Jiang Z, Du F, Wang Y (2018) Preparation of two oligopeptides from corn protein and their protective effect on acute alcohol intoxication in mice. Biomedical Research, 29: 12841289.

Tan Ş (2005) Bitki Islahında Istatistik ve Genetik Metotlar. Ege Tarımsal Araştırma Enstitüsü, Menemen, p. 251.

Tan AS (2010) Study on the Determination of Combining Abilities of Inbred Lines for Hybrid Breeding Using Line $x$ Tester Analysis in Sunflower (Helianthus annuus L.). Helia, 33: 131-148.

Tongbram SD, Baskheti DC (2014) General and specific combining ability studies in maize (Zea mays L.) using diallel mating design. International Journal of Basic and Applied Agricultural Research, 12: 48-52.

Topal A, Aydın C, Akgün N, Babaoglu M (2004) Diallel cross analysis in durum wheat (Triticum durum Desf.): identification of best parents for some kernel physical features. Field Crops Research, 87: 1-12.

Wang K, Wang W, Ye R, Liu A, Xiao J, Liu Y, Zhao Y (2017) Mechanical properties and solubility in water of corn starch-collagen composite films: Effect of starch type and concentrations. Food Chemistry, 216: 209-2. 
